\title{
TAX CONSTRAINTS ON INDEXED OPTIONS
}

\author{
DAVID M. SCHIZER ${ }^{\dagger}$
}

Indexed stock option grants reward executives for outperforming a benchmark, such as the market as a whole or competitors in the same industry. ${ }^{1}$ These options offer superior incentives by limiting the influence of factors beyond an executive's control, such as general market and industry conditions. ${ }^{2}$ Yet indexed options are almost never used. Professor Saul Levmore seeks to explain this puzzle with norms. "This comment on his article argues that tax plays a larger role in this puzzle than he acknowledges, although tax is not a complete explanation." Accounting and Professor Levmore's norms-based

† Associate Professor, Columbia University School of Law. Helpful comments were received from Marvin Chirelstein, Jeffrey Gordon, and Meredith Wolf Schizer.

'A traditional option gives the holder the right, but not the obligation, to purchase property for a set price called the "exercise" or "strike" price. For instance, an option might offer stock for the firm's then-current share price of $\$ 100$, allowing the executive to profit from appreciation above $\$ 100$. In an indexed option, in contrast, the exercise price fluctuates with some benchmark, such as the Standard \& Poor's 500 Stock Index ("S\&:P 500") or an industry basket. For instance, the option might entitle the executive to buy stock for $1 / 13$ the value of the S\&P 500 (which is assumed to be 1300 currently). For this option to yield a profit, the firm must outperform the S\&P 500 . For instance, if the firm's share price doubles to $\$ 200$ but the S\&P 500 increases even more to 3900 , the executive makes no profit (because the option yields the right to pay $\$ 300$ for stock worth $\$ 200$ ). On the other hand, if the stock declines to $\$ 80$ but the S\&:P 500 declines even more to 650 , the executive makes a $\$ 30$ profit. In basing pay on relative performance, then, indexed options reward good performance even in a falling market, without rewarding poor performers in a rising market.

* See Bengt Holmström, Moral Hazard and Observability, 10 BELL J. ECON. 74, 82-83 (1979) (noting that efficient compensation contracts filter out risk that is beyond an employee's control).

The rarity of indexed options is well known and has commonly been described as a puzzle. See, e.g., Brian J. Hall \& Jeffrey B. Liebman, Are CEOs Really Paid Like Bureaucrats?, 113 Q.J. ECON. 653, 683 \& $n .34$ (1998) (noting that indexed options "would represent a substantial improvement over current contracts" but are seldom used, and observing that "the near complete absence of relative pay seems to be a puzzle").

'The literature on norms is vast, and the term's precise meaning is debated. In general, a norm is a rule or practice that is regularly followed but not legally enforceable. For a discussion, see, for example, Melvin Eisenberg, Corporate Law and Social Norms, 99 ColuM. L. REV. 1253, 1255-57 (1999) (classifying various types of norms); Edward Rock, Saints and Sinners: How Does Delaware Corporate Law Work?, 44 UCLA L. REV. 1009 (1997) (exploring the role of Delaware courts in developing norms for corporate managers).

Tax has not previously been offered as an explanation for the indexed option 
account are then briefly considered.

\section{TAX CONSTRAINTS ON INDEXED OPTIONS}

\section{A. Section 162(m) and "Phony" Performance Pay}

The main tax advantage of traditional options over indexed ones derives from $\S 162(\mathrm{~m})$ of the Internal Revenue Code. A product of populist concerns about soaring executive pay, this rule disallows a publicly traded firm's deduction for compensation exceeding one million dollars. Yet the rule exempts performance-based pay. ${ }^{6}$ The goal of this exception is either to encourage such pay or, a cynic might say, to render the measure toothless. Both traditional and indexed options qualify as performance-based, and so the deduction for either type of option is not limited."

Traditional options have a tax advantage, though, if the parties do not want the executive to bear too much firm-specific risk. The parties will prefer pay that imposes less of this risk, but is still deductible. Traditional options thread this needle. They include a bet on the market as a whole. This value is not really performance-based, but is treated as such for tax purposes. ${ }^{8}$ For example, the option might give

puzzle. My focus on tax is unlikely to surprise Professor Levmore, who says: "I can count on my commentator to pursue the tax angle and intuitions." Saul Levmore, Puzzling Stock Options and Compensation Norms, 149 U. PA. L. REV. 1901, 1915 n.25.

${ }^{6}$ See I.R.C. $\$ 162(\mathrm{~m})(1)$ ("In the case of any publicly held corporation, no deduction shall be allowed under this chapter for applicable employee remuneration with respect to any covered employee to the extent that the amount of such remuneration for the taxable year with respect to such employee exceeds $\$ 1,000,000 . "$ ). The rule applies to the chief executive officer and to the four other most highly compensated employees. See id. $\$ 162(\mathrm{~m})(3)$ (defining "covered employee"). The term "applicable employee remuneration" does not include any remuneration "payable solely on account of the attainment of one or more performance goals" if procedural requirements are satisfied. Id. $\S 162(\mathrm{~m})(4)(\mathrm{C})$.

"For the typical "nonqualified" option, the employer has a deduction and the employee has income when the option is exercised, based on the spread between the exercise price and the value of the stock. See id. \$ 83; Treas. Reg. \$1.83-7. However, the taxable event is the grant date if the option has a "readily ascertainable fair market value," a condition that the regulations render extremely rare. "Incentive stock options" are subject to different rules, discussed below in Part I.B.

${ }^{8}$ As Professors Johnson and Tian have shown, a single traditional option is worth three times as much as a single indexed option on plausible assumptions. See Shane A. Johnson \& Yisong S. Tian, The Value and Incentive Effects of Nontraditional Executive Stock Option Plans, 57 J. FIN. ECON. 3 (2000) (noting that an indexed option is worth $\$ 13.56$ and a traditional option is worth $\$ 40.35$, assuming an at-the-money exercise price of $\$ 100$, volatility of 0.20 , a risk-free rate of $8 \%$, and a dividend yield of $2 \%$ ). The difference between the two is the bet on the market as a whole. Indeed, a traditional option 
an executive the right to buy stock for the current price of $\$ 100$. If the stock appreciates to $\$ 110$, the executive earns ten dollars-even if the rest of the market doubles, so that a ten percent return is not impressive. With a traditional option, even poor performers profit in a bull market. In contrast, an indexed option does not offer this windfall; executives are rewarded only for outperforming the benchmark (for example, competitors or the market as a whole). Thus, indexed options are more "performance-based" than traditional options, but both are deductible. Therefore, traditional options are a tax-efficient way to limit an executive's firm-specific risk. ${ }^{9}$

\section{Nonperformance Pay in Disguise: Three Pay Packages}

As an illustration of this point, three alternative pay packages are considered for an executive whose market value is $\$ 10$ million per year. To preserve its tax deduction, the firm cannot offer more than $\$ 1$ million in cash. ${ }^{10}$ Thus, the remaining $\$ 9$ million-or ninety per-

is comparable to an indexed option paired with an option on the market as a whole. For instance, assume that the traditional option authorizes purchase of the stock for $\$ 1300$ (the current price). A similar economic return is also offered by two securities: an indexed option entitling the executive to buy stock for the current value of the S\&:P 500 (which is assumed currently to be $\$ 1300$ ) and an option to buy the S\&:P for $\$ 1300$. To make the two alternatives perfectly equivalent, a "knock out" feature should be added to the indexed option, such that it makes no payment when the S\&P option is out of the money. In addition, loss on the indexed option would have to be "netted" against gains on the S\&P option in some cases. For a discussion of this netting effect, see infra note 17.

"The regulations and conference report treat options as "performance based" without requiring indexation. Treas. Reg. $\$ 1.162-27$ (e)(2) (vi) \& examples 9 through 11; see also H.R. CONF. REP. No. 103-213, pt. 4 (1993). The exercise price must be no less than the stock price on the grant date. Cf. MARIN A. CHIRELSTEIN, Federal INCOME TAXATION (7th ed. 1994) (noting that the legislative history of $\$ 162(\mathrm{~m})$ "apparently regards 'performance' as an absolute rather than a comparative measure of executive success").

1" Recent empirical studies confirm that firms often respect the $\$ 1$ million cap (although, in the current bear market, large nondeductible grants of restricted stock reportedly are becoming more common). For instance, one study of 376 firms documented that most responded to the enactment of $\$ 162(\mathrm{~m})$ by qualifying top executive pay as performance-related. See Peter Woodlock \& Joseph W. Antenucci, Update: Corporate Responses to Executive Compensation Deductibility Limits, TAX NOTES, Oct. 13, 1997, at 221; see also BRIAN J. HALl \& JEFFREY B. LIEBILAN, THE TAXATION OF EXECUTIVE COMPENSATION (Nat'l Bureau of Econ. Research, Working Paper No. 7596, 2000) ("We did find that the million dollar rule led companies to substitute performancebased pay for salary. But our evidence suggests that this substitution was quite modest ...."); Tod Perry \& Marc Zenner, Pay for Performance? Government Regulation and the Structure of Compensation Contracts (June 2000) (unpublished manuscript) ("[W']e find that after 1993 the salary growth rate is significantly smaller for firms near 
cent of the pay package-must be offered through options, which could be indexed or traditional. ${ }^{11}$

An appeal of traditional options is that a $\$ 9$ million traditional grant conveys far less firm-specific risk than $\$ 9$ million of indexed options-indeed, about half as much, since traditional options also include a valuable market bet. ${ }^{12}$ Of course, some firm-specific risk is needed to produce useful incentives. But if too much is imposed, undiversified executives could demand an unduly high premium." Moreover, as Professor Levmore emphasizes, too much firm-specific

or above the million-dollar threshold. We also find that most firms reducing salaries to a level at or below one million dollars do so in response to $162(\mathrm{~m})$. On the other hand, these salary reductions do not lead to lower total compensation."), available at http://papers.ssrn.com/sol3/papers.cfm?cfid=450743\&cftoken=73769900\&abstract_id =60956; Nancy L. Rose \& Catherine Wolfram, Regulating Executive Pay: Using the Tax Code to Influence CEO Compensation (Sept. 2000) (unpublished manuscript) (finding that cash salaries cluster around $\$ 1$ million, with growth in compensation concentrated in option grants and other performance-based payments), available at http:/ papers.ssrn.com/sol3/papers.cfm?cfid $=450743 \&$ ccftoken $=73769900 \&$ cabstract_id $=244570$. Preserving the deduction under $\$ 162(\mathrm{~m})$ reportedly has public relations benefits, as well as tax benefits. See Perry \& Zenner, supra, at 8 (citing a survey by Investor's Business Daily that indicates that eighty-seven percent of firms mentioned shareholder relations as a reason to preserve the deduction under $\$ 162(\mathrm{~m})$ ).

${ }^{11}$ The firm could also include a performance-based bonus, but this alternative is ignored here for simplicity's sake. As discussed below, for the bonus to qualify as performance-based, it must also present real firm-specific risk.

${ }^{12}$ As Professors Johnson and Tian have shown, the indexed option grant will be almost twice as sensitive to changes in the stock price as a traditional grant of equivalent value. See Johnson \& Tian, supra note 8, at 16-17 (noting that delta of an indexed grant is ninety-three percent larger than delta of a traditional grant).

${ }^{13}$ Executives are undiversified because their human capital is tied to firm performance. The size of the premium will depend upon their risk preferences and the rest of their portfolios. Too much risk is imposed if the premium rises more than the added productivity benefits from intensifying the incentive. See Brian J. Hall \& Kevin J. Murphy, Optimal Exercise Prices for Executive Stock Options, 90 AM. ECON. REv., PAPERS \&c PROCS. OF THE ONE HUNDRED TWELFTH ANN. MEETING OF THE AM. ECON. ASS'N, May 2000, at 209; see also Lisa K. Meulbroek, The Efficiency of Equity-Linked Compensation: Understanding the Full Cost of Awarding Executive Stock Options (Mar. 1, 2000) (unpublished manuscript) (stating that an undiversified executive's subjective valuation of equity compensation will be lower than a diversified investor's valuation, leading to deadweight loss when such compensation is used), available at http://papers.ssm.com/sol3/papers.cfm?cfid=450743\&cftoken=73769900\&abstract_id $=215530$. In response, executives theoretically could seek diversification in the derivatives market. If such hedging with derivatives is feasible, executives should not receive a premium for accepting firm-specific risk and, of course, no useful incentives would be created. Yet tax and securities law have impeded such hedging, as should contractual limitations imposed by the firm. David M. Schizer, Executives and Hedging: The Fragile Legal Foundation of Incentive Compatibility, 100 COLUM. L. REV. 440, 501-02 (2000). 
risk could induce the executive to take foolish gambles. ${ }^{14}$

If the point is to reduce firm-specific risk, traditional options are not the only way. Instead, the firm could offer a smaller grant of indexed options (for example, $\$ 4.5$ million) and more cash (for example, $\$ 5.5$ million). ${ }^{15}$ Yet because of $\$ 162(\mathrm{~m})$, the firm could not deduct $\$ 4.5$ million of cash, and thus would owe almost $\$ 1.6$ million of extra tax."

While traditional options preserve the firm's deduction, they impose two offsetting costs. First, the executive must bear general market risk. ${ }^{17}$ Second, these options provide less effective incentives in a falling market, a factor that may prove increasingly important in coming years. To compensate the executive for these costs, the firm must share the tax savings. For instance, the executive's option grant can be increased from $\$ 9$ million to $\$ 10$ million. In some cases, a relatively modest premium will suffice. Market risk in the options is acceptable if the executive would have invested in the market anyway. ${ }^{18}$

"As Professor Levmore notes, indexed options encourage executives to take risk, ven more than traditional options do. Risk-promoting compensation is helpful in some cases, since executives tend to be more risk averse than diversified shareholders. Yet too much promotion of risk could lead to risks with negative present value. Levmore, supra note 5 , at 1922-24.

"Se id. at 1920 (noting that incentive compatibility of traditional options can be replicated through cash and indexed options). This package has the advantage of filtering out unwanted market risk and providing useful incentives even in a bear market.

"Loss of a $\$ 4.5$ million deduction would cost the firm $\$ 1.575$ million, assuming the $35 \%$ federal corporate tax rate applies.

${ }_{17}$ Even those who want market risk would rather get it by investing cash salary in S\&:P options. If this market bet is embedded in a traditional option, profits can be offset by firm-specific losses. Yet such "netting" would not occur if the executive received S\&P options (or cash used to purchase them) and separate indexed options. To see the difference, compare two scenarios. First, assume the executive receives a traditional option to buy stock for its current market price of $\$ 1300$ (which is also assumed to he the current value of the S\&:P 500). What if the firm stock price remains at $\$ 1300$, even though the S\&P 500 increases to $\$ 2300$ ? The executive has no profit. In contrast, assume the executive receives an indexed option to buy stock for the current value of the S\&P 500, and also uses cash to buy a separate at-the-money S\&P call option with an exercise price of $\$ 1300$. On the assumed facts, the executive nets a $\$ 1000$ profit on the Sx:P option. Even though the stock underperformed the S\&:P 500 by $\$ 1000$, the executive has no loss on the indexed option (other than the salary foregone to get it). Unlike the traditional option, this $\$ 1000$ underperformance does not cancel out the $\$ 1000$ profit on the S\&P option.

is $S_{\ell} \mathrm{Li}$ Jin, CEO Compensation, Diversification and Incentives 32 (Dec. 9, 2000) (unpublished manuscript) ("[T]he cost to [the] firm of moving market risk from shareholder[s] to the CEOs is not high.... CEOs naturally want to hold some market risk as long as it is fairly priced. Even if CEOs are given only risk-free cash compensation, they are likely to invest some of their wealth in the risky assets themselves...."), available at http://papers.ssrn.com/sol3/papers.cfm?cfid= 
Likewise, the risk of being undercompensated in a falling market is less daunting if executives expect to be made whole ex post, for instance, through repricing of existing grants or larger future grants. The three pay packages are compared in the following table:

Table 1: Comparison of Three Pay Packages

\begin{tabular}{|c|c|c|}
\hline Pay Package & Firm-Specific Risk & $\begin{array}{c}\text { Nondeductible } \\
\text { Portion }\end{array}$ \\
\hline $\begin{array}{c}\$ 1 \text { million cash } \\
\$ 9 \text { million indexed } \\
\text { option }\end{array}$ & $\begin{array}{c}\text { Intense } \\
\text { concentration }\end{array}$ & 0 \\
\hline $\begin{array}{c}\$ 1 \text { million cash } \\
\$ 9 \text { million traditional } \\
\text { option }\end{array}$ & Less intense & 0 \\
\hline $\begin{array}{c}\$ 5.5 \text { million cash } \\
\$ 4.5 \text { million indexed } \\
\text { option }\end{array}$ & $\begin{array}{c}\text { Less intense (like } \\
\$ 9 \text { million tradi- } \\
\text { tional option) }\end{array}$ & $\$ 4.5$ million cash \\
\hline
\end{tabular}

2. Section $162(\mathrm{~m})$ Cannot Be the Whole Story

Thus, $\$ 162(\mathrm{~m})$ inadvertently favors traditional options over indexed ones-a distortion that justifies repeal of this measure. Even so, $\S 162(\mathrm{~m})$ is only a partial explanation. Indexed options were rare even before this rule was enacted in 1993. In some cases, the tax benefit to the firm should be less than the nontax cost to the executive (for example, extra market risk in a bear market). Moreover, the rule should have less influence for firms that are subject to a low tax rate. ${ }^{19}$ In addition, $\S 162(\mathrm{~m})$ cannot explain why less-senior executives (who are not subject to the rule) receive traditional instead of indexed grants. Finally, other compensation is not entirely performance-based, but still qualifies as such under $\$ 162(\mathrm{~m})$. For instance, cash bonuses could be based on lax "performance" standards (for ex-

$450743 \&$ cftoken $=73769900 \&$ abstract $\_i d=254260$. The return on the underlying stock, and thus on the traditional option, should already include a premium for market risk. Thus, an extra premium is more likely to be demanded for firm-specific risk (which cannot be diversified away). See Meulbroek, supra note 13 (emphasizing "loss of diversification cost" associated with firm-specific risk).

${ }^{19}$ On the other hand, the deduction from options comes in future tax years (that is, when options are exercised) and so a firm may be less certain, ex ante, of being in a low bracket. 
ample, sales of at least eighty percent of last year's volume). A problem with this alternative, though, is that the tax rule requires a meaningful chance of failing the performance standard. ${ }^{20}$ Yet such risk is precisely what the parties may be trying to avoid."

\section{B. Indexing Incentive Stock Options}

A second tax constraint is that so-called incentive stock options ("ISOs") arguably cannot be indexed. ISOs offer capital gain treatment to the executive, albeit at the cost of no deduction for the employer. "For the option to qualify as an ISO, the "option price" must not be "less than the fair market value of the stock at the time such option is granted." ting indexed options as long as, on the grant date, the index is at least as valuable as the stock price. ${ }^{24}$ However, meeting this test on the grant date arguably is not sufficient under the regulations: The "option price"-which is defined as the price actually paid on the op-

"Sr, r.g., Treas. Reg. $\$ 1.162-27$ (e)(2) (i) (noting that pay is not performancebaved unless the performance goal "outcome is substantially uncertain at the time the compensation committee actually establishes the goal").

${ }^{2}$ Professor Calvin Johnson has observed a tax inefficiency in any option that is scttled with stock (whether traditional or indexed). After the option is exercised, the executive will hold stock. Unlike debt, stock generates no deductions to the firm. See Calvin H. Johnson, Stock Compensation: The Most Expensive Way To Pay Future Cash, 52 S.M.U. L. REV. 423,425 (1999). Yet this problem is fixed if, at the same time, the firm borrows to repurchase shares from investors. In fact, firms commonly hedge option grants with such leveraged equity repurchases. Cf. Haim A. Mozes \& Steven B. Raymar, Granting and Hedging Employee Stock Options: A Tax Motivation and Empirical Tests 4 (Sept. 15, 2000) (unpublished manuscript) ("In a dynamic hedging strategy, the [firm] borrows funds and purchases equity when the options are first isstled."), atrailable at http://papers.ssrn.com/sol3/delivery.cfm/SSRN_ID243632_ code001022520.pdfecfid $=450743 \&$ cftoken $=73769900 \&$ abstractid $=243632$. The result is essentially the same as if the firm borrowed money to pay executives in cash (for example, on an indexed stock appreciation right), which is the approach Professor Johnson recommends.

$\therefore$ Specifically, the executive owes no tax upon exercising the option and will report capital gain from selling the stock as long as the stock is held until at least one year after the date of exercise and two years after the option grant date. However, extrcise of the option can trigger alternative minimum tax. See Barbara J. Raasch \& Judith L. Rowland, Stock Option Planning, TAXES, Jan. 1999, at 39 (discussing tax treatment of ISOs).

I.R.C. $\$ 422$ (b) (4).

For instance, assume that the stock is worth $\$ 100$, the $\$ \& P 500$ is at $\$ 1300$, and the option's exercise price is $1 / 13$ of the S\&P 500. Under this reading of the statutory linguage, the option could be an ISO. Professor Levmore apparently reads the language in this way. See Levmore, supra note 5, at 1913. 
tion $^{25}$-"may be determined in any manner so long as the minimum price possible under the terms of the option cannot be less than the fair market value of the stock at the date of grant." ${ }^{26}$ An indexed option cannot satisfy this condition because the exercise price could fall below this minimum value at some point during the life of the option (for example, as the index falls). ${ }^{27}$

Even so, the significance of this tax constraint on indexed ISOs should not be overemphasized. The statutory language arguably permits ISOs to be indexed, and there is no policy reason to disfavor indexation. As a result, the Treasury should be willing to change the regulation. Yet to my knowledge, no one is lobbying for this reform. Stakes are low, in any event, because ISOs are relatively uncommon. The tax savings to the executive (which is generally the difference between the maximum tax bracket of $39.6 \%$ and the long term capital gains rate of $20 \%$ ) is usually less than the tax cost to the employer (a $35 \% \operatorname{tax}) .^{28}$ As a result, these options are tax-advantaged only for firms that do not pay corporate tax (for example, because they have losses). (Note, though, that these are precisely the firms that would be less influenced by $\S 162(\mathrm{~m}))$. Even for these firms, the size of ISO grants is strictly limited. ${ }^{29}$ Thus, the need to qualify for ISO status is at most a

${ }^{25}$ See Treas. Reg. $\$ 1.421-7$ (e) (1) (defining option price as "the consideration in money or other property which, pursuant to the terms of the option, is the price at which the stock subject to the option is purchased") (emphasis added). added).

${ }^{26}$ Prop. Treas. Reg. 1.422A-2(e), 49 Fed. Reg. 4504 (Feb. 7, 1984) (emphasis

${ }^{27}$ In defense of indexed options, one might read this language to require only that the minimum price, as of the grant date, cannot be less than the fair market value of the stock on the grant date. In other words, one could read the phrase "on the grant date" to refer to the entire sentence, and not just the immediately preceding language "fair market value of the stock." Yet this reading is inconsistent with the definition of "option price" as the price actually paid (and not the price that hypothetically would be paid on the grant date). See Treas. Reg. $\$ 1.421-7$ (e) (1) (defining the term "option price"). In addition, this reading yields bizarre results. What if the exercise price equals the stock price on the grant date but is preset to decline thereafter (for example, by a dollar a day until it reaches zero)? Tested only on the grant date, this option would qualify as an ISO. Yet this is precisely the kind of option that is not supposed to qualify. Indeed, the prior regime for "restricted stock options" explicitly required the option price to be "fixed or determinable at the time the option is granted." Otherwise, the option would be a so-called "variable price option" that was not eligible for favorable tax treatment. See Treas. Reg. $\$ 1.421-1$ (d) (2) (describing the requirements for granting a restricted stock option).

${ }^{28}$ Se $e$ MYRON S. SCHOLES \& MARK A. WOLFSON, TAXES AND BuSINESS STRATEGY 188-89 (1992) (showing that the tax cost to the firm exceeds the tax benefit to the executive, assuming the same tax rate governs both parties).

${ }^{29}$ For each executive, the underlying shares cannot be worth more than $\$ 100,000$ in a given year. 
partial explanation for the scarcity of indexed options.

\section{ACCOUNTING}

The conventional view is that financial accounting favors traditional options by not expensing them on the firm's income statement. In contrast, indexed options are expensed; the amount of expense varies over time, depending on changes in the option's intrinsic value. ${ }^{3 / n}$ Professor Lermore questions the importance of this accounting difference. Investors in an efficient market should ignore accounting conventions, he notes, and thus should prefer a better incentive to padded earnings.

On the other hand, when the Financial Accounting Standards Board sought to expense option grants in the early 1990s, firms hired lobbyists and spent political capital to block this accounting change. Real resources are also devoted in other contexts to enhance earnings. ${ }^{31}$ If accounting really has no significance, as some academics suggest, why the fuss?

Since sophisticated parties often behave as if stock options accounting is significant, it is worth considering reasons why they may be

"Thus, for traditional options, no expense is recorded in the body of the income statement when the option is granted or exercised. Traditional options qualify for this treatment only if the exercise price is at least as high as the stock price on the grant date. Under a 1995 reform, the option's grant date value (based on Black-Scholes or other reasonable valuation models) - but not subsequent changes in value-must now be reflected in a footnote on the income statement. In contrast, because indexed options are treated as "variable" options, the income statement includes an expense based on the option's built-in gain during each period (that is, the option's intrinsic value, as opposed to its Black-Scholes value).

For instance, firms used to incur extra costs to issue securities treated as debt for tax purposes, but not for accounting purposes. See, e.g., Ellen Engel et al., Debt-Equity Hybrid Securities, J. ACCT. RES., Oct. 1, 1999, at 249 (1999) (studying MIIPS and other securities treated as debt for tax purposes but not for rating agency and accounting purposes, and noting that firms incur extra expenses totaling approximately four percent of the offering price to secure better accounting treatment for otherwise comparable securities). Likewise, some firms have stopped engaging in tax-advantaged hedging transactions because these transactions would introduce volatility in accounting earnings under FAS 133, a new accounting rule for derivatives. See David M. Schizer, Frirtions as a Constraint on Tax Planning, 101 CoLUM. L. REv. (forthcoming 2001); see alsa Douglas A. Shackelford \&: Terry J. Shevlin, Empirical Tax Research in Accounting (Dec. 2000) (unpublished manuscript) (describing studies of the tradeoff between accounting and tax reduction in the use of LIFO, compensation, depreciation, income shifting, capital structure, acquisitions, etc.), available at http://papers.ssrn.com/ sol3/delivery.cfm/SSRN_ID235796_code000828530.pdfecfid=4507438.cftoken=737699 00\&abstractid $=235796$. 
correct. First, information can be costly. ${ }^{32}$ To measure the true cost of options, investors must value them not only on the grant date, but also over time (and for traditional options, unlike for indexed options, this information is not supplied on accounting statements). These periodic reevaluations are costly. Indeed, economists have been reluctant to undertake this effort in a related context. Studies of the link between pay and performance usually ignore post-grant-date fluctuations in the value of equity compensation. ${ }^{38}$ Since economists find these computations daunting, it would not be surprising if investors do as well.

Of course, some investors should be willing to bear this cost if they could profit from superior information. For instance, assume that unsophisticated investors, misled by accounting conventions, bid up the price of a given security. In a well-functioning market, sophisticated investors, who have done enough research not to be fooled, should do short sales that return the price to an appropriate level. ${ }^{34}$ Yet sophisticated investors will not take this step unless they expect the rest of the market to follow them within a reasonable period of time. If they expect unsophisticated investors to continue to rely on accounting numbers, less arbitrage will be supplied. ${ }^{35}$

${ }^{32}$ See Sanford Grossman, On the Efficiency of Competitive Stock Markets Where Traders Have Diverse Information, 31 J. FN. 573 (1976); Sanford J. Grossman \& Joseph E. Stiglitz, On the Impossibility of Informationally Efficient Markets, 70 AM. ECON. REV. 393 (1980) (showing that competitive markets break down when information is costly); $c f$. Richard A. BREAley \& STEWART C. MYERS, PRINCIPLES OF CORPORATE FINANCE 363 (6th ed. 2000) (considering the possibility that investors sometimes respond slowly to new information).

As they put it,

${ }^{33}$ A notable exception is the insightful study of Brian Hall and Jeffrey Liebman.

[i]t is worth stating from the outset why our results differ from previous find-

ings. With regard to the large literature that indicates that salary and bonus elasticities are small, our findings differ simply because previous estimates ignored changes in the value of stock and stock options, which account for virtually all of the sensitivity.

Hall \& Liebman, supra note 3 , at 655.

${ }^{34}$ A short sale is a bet that the market will decline. The short seller sells borrowed property, hoping to buy it later for a lower price.

${ }^{35}$ An analogy may be drawn to the "noise trader" literature. The existence of speculative bubbles or panics is puzzling in an efficient market. Instead, we would expect sophisticated investors to arbitrage these price swings. For instance, if unsophisticated investors (or "noise traders") are paying too much for tulips or internet stocks, sophisticated investors should engage in short sales that yield a profit once the bubble bursts and, indeed, should help it to burst. Why, then, do bubbles ever occur? The "noise trader" literature contends that sophisticated investors will do these short sales only if they expect the market to decline in the near term. If there is doubt about when (or whether) the "noise traders" will recognize their error, arbitrage becomes 
This is not to say that accounting alone explains the lack of indexed options, although the role of accounting warrants further study." I agree with Professor Levmore that it is useful also to seek explanations more consistent with a well-functioning market.

\section{NONCONFLICTING FORTUNES}

Professor Levmore offers a two-step argument. First, indexed options are not appropriate for all executives. His reason is that these options can induce excessive risk-taking and thus can be given only to executives who are readily monitored. (As a friendly amendment, he might add that $\$ 162(\mathrm{~m})$ discourages indexed grants to some highly compensated executives.) Second, a firm will resist giving indexed options to a subset of executives. The problem, he argues, is that pay of different employees could be negatively correlated, violating the norm of "nonconflicting fortunes." In a falling market, for instance, indexed option holders could prosper. But colleagues holding traditional options would not.

While this argument has much to commend it, two concerns come to mind. First, are negative correlations in pay as rare as he suggests? For instance, employees often compete for the same promotion. ${ }^{37}$ Likewise, division heads may be paid for division-specific performance, with one division doing well while others do not. Second, is this really a norms story? Instead, as Professor Levmore acknowledges, straightforward efficiency concerns may be at work. In avoiding negative correlations in pay, the firm may simply be building team morale and avoiding interemployee conflict.

The more general point is that, in designing compensation packages, firms consider factors other than the two-incentives and em-

very risky and less of this service is supplied. See generally J. Bradford De Long et al., Noist Trader Rask in Financial Markets, 98 J. POL. ECON. 703 (1990) (presenting a "model of an asset market in which irrational noise traders with erroneous stochastic beliefs both affect prices and earn higher expected returns"); Andrei Shleifer \& Lawrence H. Summers, The Noise Trader Approach to Finance, 4 J. ECON. PERSP. 19, 19-20 (1990) ("[S]ome investors are not fully rational and their demand for risky assets is affected by their beliefs or sentiments that are not fully justified by fundamental news. [In addition,] arbitrage ... is risky and therefore limited.").

"For one thing, we might expect firms that are less concerned about accounting to implement indexed options. For instance, cable firms are said to be evaluated based on the number of subscribers rather than on accounting earnings. Yet cable firms do not use indexed options either. n. 59 .

\footnotetext{
Professor Levmore acknowledges this point. See Levmore, supra note 5, at 1933
} 
ployee risk-aversion-emphasized in the finance literature on indexed options. For instance, it may be helpful to explain the CEO's large pay package by saying it is performance-based, even if this is not entirely the case. Thus, the ability of traditional options to offer nonperformance pay "in disguise"-a feature with tax advantages, as discussed above-may also facilitate dealings with unions, regulators, and even shareholders, although sophisticated investors should not be fooled. In addition, compensation committees may not want to be the first to adopt a novel method of compensation. Furthermore, indexation raises the choice of a suitable benchmark. If the executive must outperform competitors, which ones? What if the firm is a conglomerate? What about competitors that are not publicly traded? If the benchmark is a particular industry, instead of the market as a whole, executives have an incentive to imitate ${ }^{38}$ or scuttle competitors, even if these efforts do not advance their own shareholders' interests. ${ }^{39}$ Likewise, if the industry is the benchmark, the executive is not credited (or penalized) for the choice of which industry the firm is in. For instance, a typewriter manufacturer might outperform other typewriter manufacturers, but managers arguably should be penalized for failing to sell computers. On the other hand, if the benchmark is the entire market, managers would be rewarded (or penalized) for being in a "hot" (or "dead") sector, a result driven in part by luck. In addition, managers in high "beta" firms could profit in a rising market (that is, as the stock predictably rises more than the general market), while managers in low beta firms would profit in a falling market (that is, as the stock predictably falls less than the market). ${ }^{40}$

More generally, the appeal of indexed options is not as straightforward as the finance literature suggests. Professor Levmore makes this case elegantly and persuasively. Norms may play a role, along

${ }^{38}$ Cf. PAul A. GOMPERS \& JOSH LerNer, THE Venture CAPITAL CYCle (1999) (noting that when venture capitalists are evaluated on a relative basis, they may respond by imitating each other's portfolios to avoid falling behind).

${ }^{39}$ Professors Aggarwal and Samwick take the point one step further. They argue that collusion among rival firms can advance shareholder (although not societal) interests. Indexed options are avoided because they would impede such collusion. See Rajesh Aggarwal \& ANDrew A. Samwick, Executtve Compensation, Strategic CompettTion, and Relative PERformance Evaluation: THeORY and Evidence, (Nat'l Bureau of Econ. Research, Working Paper No. 5648, 1996). Yet this theory bears only on the choice not to index against industry competitors. The theory does not explain the absence of indexation against the market as a whole.

${ }^{40}$ Beta describes the sensitivity of a stock to general movements in the market. Stocks with high betas are very sensitive and thus go up (and down) more than the general market. See BREALEY \& MYERS, supra note 32, at 173-75. 
with accounting, a range of governance concerns, and the tax constraints emphasized here. 
